\title{
PENTINNGNYA PENGAPLIKASIAN BERPIKIR KRITIS BAGI PERAWAT DI IGD
}

\author{
Cut Tari \\ E-Mail cuttari19@gmail.com
}

\begin{abstract}
Abstrak
Latar belakang:Dalam perawatan di instalasi gawat (IGD) darurat begitu bervariasi mulai dari kasus yang sederhana hingga kasus yang kompleks sehingga perawat harus menyelesaikan serta menemukan solusi untuk menyelesaikan masalah atau mengambil keputusan yang dihadapinya dengan cepat dan tepat , untuk itu perawat dituntut untuk dapat mengaplikasikan cara berpikir kritis dalam bekerja dan mengambil keputusan supaya tercipta pemberian asuhan keperawatan yang baik dan berkualitas kepada pasien. Tujuan:untuk menganalisa serta mengetahui pentingnya pengaplikasian berpikir kritis bagi perawat di unit instalasi gawat darurat. Metode: Metode yang digunakan oleh penulis adalah Literature review dimana dilakukan dengan cara menganalisis kajian, eksplorasi jurnal, membaca text book,tesis maupun e-book yang relevan dan membahas tentang kemampuan berpikir kritis bagi perawat.Adapun jurnal yang digunakan pada literature review ini adalah jurnal yang diterbitkan dari kurun waktu 10 tahun terakhir yang didapatkan dengan menggunakan dua database Portal Garuda dan Google Scholar dan referensi yang digunakan sebanyak 14. Kesimpulan: ketika perawat tersebut mengaplikasikan berpikir kritis maka perawat tersebut tidak hanya memandang suatu masalah dari sudut pandang dirinya saja tapi melalui banyak sudut pandang lainnya perawat yang mengaplikasikan berpikir kritis berpeluang memberikan asuhan keperawatan yang lebih baik,karna dalam mengambil keputusan perawat tersebut lebih tepat dan cepat .
\end{abstract}

Kata Kunci: Bepikir Kritis, Perawat,Instlasi Gawat Darurat.

\begin{abstract}
Background: In emergency department (ER) treatment varies from simple cases to complex cases nurses must solve and find solutions to solve problems or make decisions they face quickly and correctly, for that nurses are required to be able to use apply how to think critically at work and make decisions asking for good and quality nursing assistance for patients. Purposes: to analyze and think about the importance of the application for the emergency department. Methods: The method used by the author is Literature Review which is done by analyzing, exploring journals, reading textbooks, as well as relevant e-books and discussing critical thinking skills for nurses. As for the journals used in this literature review are published journals. by the past 10 years obtained using the two portal garuda databases and Google Scholar and references that are used are 14. Conclusion: the compilation of nurses who have applied criticism then the nurse does not only consider the problem from the point of view only other views nurses who apply critical thinking has the opportunity to provide better nursing care, because nurses make decisions more precisely and quickly.
\end{abstract}

Keywords: Critical Thinking, Nurse, Emergency Room. 
PENDAHULUAN

\section{Latar Belakang}

Bagi perawat yang bekerja di rumah sakit khususnya yang bekerja di IGD berpikir kritis pada saat mengambil keputusan sangatlah penting. Berpikir kritis dalam keperawatan merupakan keterampilan bagaimana seorang perawat mengambil keputusan dengan cara tidak memandang satu permsalahan itu hanya dengan satu sudut pandangnya saja,namu memandang suatu permasalahan tersebut dengan rasional untuk memecahkan masalah tersebut.

Sebagai perawat berpikir kritis adalah sesuatu yang sangat penting dilakukan oleh perawat sebelum mengambil keputusan dalam asuhan keperawatan. Asuhan keperawatan merupakan satu metode ilmiah dalam penyelesaian masalah klien. Kemampuan perawat mengidentifikasi masalah klien dan memilih solusi intervensi yang tepat tidak lepas dari kemampuan perawat berpikir kritis,yaitu kemampuan perawat menggali alasan berdasarkan evidence base dari setiap problem dan solusi yang teridentifikasi. Kemampuan berpikir kritis dan disposisinya dapat digunakan ketika menyelesaikan masalah keperawatan (BambangSudono,dkk,2017).

\begin{tabular}{lcr}
\multicolumn{1}{c}{ Berpikir } & kritis & dalam \\
pengaplikasian & didasarkan pada \\
pengetahuan & pengalaman ,
\end{tabular}
kompetensi berpikir kritis, sikap ,dan standar ketika seorang perawat sudah berhasil mengaplikasikan pola berpikir kritis maka perawat tersebut sudah dipastikan memiliki pendekatan yang adil ,beralasan,dan inovatif terhadap pertimbangan yang telah diambilnya.

Seorang perawat Kualitas pelayanan keperawatannya tidak bisa terlepas dari peran klasifikasi pasien diruang rawat inap, karena dengan klasifikasi tersebut pasien merasa lebih dihargai sesuai haknya dan dapat diketahui bagaimana kondisi dan beban kerja perawat di masing-masing ruang rawatan. Dimana kondisi serta beban kerja di instalasi gawat darurat (IGD) perlu diketahui agar dapat ditentukan kebutuhan kuantitas dan kualitas tenaga perawat yang diperlukan dalam ruang IGD sehingga tidak akan terjadi beban kerja yang tidak sesuai yang akhirnya menyebabkan perawat mengalami stres kerja.Maka dari itu bagi perawat 
yang bekerja di IGD sangat diperlukan menyelesaikan masalah dengan cara berpikir kritis .

Kondisi kerja berupa situasi kerja yang mencakup fasilitas, peraturan yang diterapkan, hubungan sosial kerjasama antar petugas yang dapat mengakibatkan ketidak nyamanan bagi pekerja. Demikian juga dengan beban kerja baik secara kuantitas dimana tugas-tugas yang harus dikerjakan terlalu banyak/sedikit maupun secara kualitas dimana tugas yang harus dikerjakan membutuhkan keahliahan.Ketika kita berpikir kritis maka kita akan memandang suatu masalah tersebut tidak hanya dari sudut pandang kita saja melainkan dari sudut pandang lingkungan maupun rekan-rekan kerja yang lainnya.

\section{Metode Penelitian}

Metode yang digunakan oleh penulis adalah Literature review dengan cara menganalisis, kajian dan eksplorasi jurnal, text book, maupun ebook yang relevan dan membahas tentang kemampuan berpikir kritis bagi perawat.

Adapun jurnal yang digunakan pada literature review ini adalah jurnal yang diterbitkan dari kurun waktu 10 tahun terakhir didapatkan dengan menggunakan 2 database Portal Garuda dan Google Scholar dengan memasukkan kata kunci " Kemampuan Berpikir Kritis”, "Perawat IGD", "Berpikir Kritis ". Artikel yang digunakan minimal menggunakan 14 referensi .

\section{Hasil Penelitian}

Berdasarkan hasil pencarian literatur didapatkan pentingnya pengaplikasian berpikir kritis bagi perawat di IGD.

Dalam literature review tersebut penelitian ini mendapatkan hasil bahwa untuk meningkatkan kemampuan berpikir kritis bagi perawat yang berada di IGD dapat dilakukan dengan metode menganalisis maupun mengeksplorasi referensi yang telah disesuaikan dengan pengkajian.Hasilnya dapat disimpulkan bahwa Kemampuan berpikir kritis dipengaruhi oleh berbagai faktor.Antara lain faktorfaktor yang mempengaruhi kemampuan berpikir kritis adalah kondisi fisik, keyakinan diri / motivasi, kecemasan, kebiasaan dan rutinitas, perkembangan intelektual, konsistensi, perasaan atau emosi, dan pengalaman (mulyaningsih,2009). 


\section{Dalam berpikir kritis}

komunikasi merupakan suatu proses karena melalui komunikasi seseorang menyampaikan dan mendapatkan respon. Bagi perawat yang bekerja di IGD keterampilan ini adalah sebuah keterampilan mutlak yang harus dimiliki, karena dengan komunikasi seorang perawat dapat melaksanakan asuhan keperawatan secara profesional dalam mengimplementasikan berpikir kritisnya ,karna dengan begitu perawat dapat mengumpulkan data pengkajian, mengumpulkan data fokus untuk menegakkan diagnosa keperawatan serta dengan komunikasi akan memperlancar semua tindakan keperawatan yang direncanakan sampai ke proses pemberian pendidikan kesehatan pada pasien.

\section{PEMBAHASAN}

Kemampuan perawat dalam berpikir kritis dapat memberikan pandangan yang luas karena tidak memandang suatu permasalah dengan satu sudut pandang saja dan kemampuan perawat dalam berpikir kritis juga menjadi solusi kreatif yang dibutuhkan untuk keberhasilan peningkatan kualitas asuhan keperawatan.

Proses berpikir kritis akan meningkatkan kemampuan perawat yang bekerja di IGD untuk mengidentifikasi indikator-indikator klinis, mengkaji signifikansinya dan mendiskusikan area-area yang harus dikembangkan dengan rekan medis lainnya untuk mendapatkan hasil dari permasalahan tersebut. Berpikir kritis dalam keperawatan merupakan komponen yang sangat penting dari akuntabilitas professional dan salah satu penentu kualitas asuhan keperawatan. Perawat yang memiliki kemampuan berpikir kritis akan menunjukkan sikap percaya diri, berpandangan konseptual, kreatif, fleksibel, rasa ingin tahu, berpikiran terbuka, tekun dan reflektif, dimana perawat IGD yang dituntut supaya dapat bekerja cepat dan tepat akan sangat membantu menolong pasien jika mereka melakukan berpikir secara kritis .

Rata-rata tenaga keperawatan yang bekerja di IGD telah meiniliki pengalaman yang cukup dalam melaksanakan tugas dan pekerjaan, sehingga diharapkan para perawat 
yang bekerja di IGD dapat meningkatkan kualitas pelayanan serta memberikan asuhan keperawatan kepada pasien secara profesional. Lama bertugas atau masa kerja menggambarkan pengalaman seseorang dalam menguasai bidang tugasnya, pada umumnya petugas dengan pengalaman kerja yang banyak tidak memerlukan banyak bimbingan dibandingkan dengan petugas yang pengalaman kerjanya sedikit , jadi ketika perawat mengaplikasikan penerapan berpikir kritis di IGD maka jika perawat tersebut adalah perawat yang baru ,perawat tersebut tidak hanya memandang cara menyelesaikan suatu masalah tersebut hanya dengan caranya saja tetapi juga dengan cara perawat lain yang sudah lama bekerja di IGD tersebut, sehingga nantinya akan muncul inovasi inovasi baru hasil dari penggabungkan cara pandang dari dua sudut yang berbeda,begitu pula dengan perawat lama ketika menerapkan cara berpikir kritis ketika melakukan tindakannya ,perawat tersebut tidak akan memandang cara penyelesaian dari sudut pandang mereka saja tetapi dari banyak aspek .

\section{Hubungan berpikir kritis dengan motivasi}

Penelitian menunjukkan bahwa tidak terdapat hubungan yang signifikan antara motivasi dengan kemampuan berpikir kritis perawat . Hal ini menunjukkan bahwa ternyata motivasi saja tidak cukup secara bermakna untuk meningkatkan kemampuan berpikir kritis. Berdasarkan data mean pada variabel motivasi, maka domain insentif merupakan nilai mean yang paling rendah. Insentif merupakan indikator yang penting dalam memotivasi seseorang. Hal ini sesuai dengan pendapat Kopelman yang menyatakan bahwa imbalan akan mempengaruhi seseorang untuk meningkatkan motivasi kerjanya yang secara langsung dapat meningkatkan kinerjanya. Hal yang sama dinyatakan oleh Musni Riza (2002) yang menyatakan bahwa salah satu faktor yang menyebabkan motivasi kerja 102 Jurnal Ilmu Keperawatan Indoensia Vol. 10, No. 1, April 2017 perawat berkurang adalah reaward yang tidak ada

(Bambang

Sudono,dkk,2017).Ternyata

pemberian reaward kepada perawat yang telah berhasil mengerjakan pekerjaannya dengan baik dapat meningkatkan motivasi kerja perawat 
tersebut sehingga ketika perawat bekerja dapat melakukan pekerjaan tersebut dengan baik .

\section{Hubungan antara banyaknya kunjungan pasien di IGD dengan pengaplikasian berpikir kritis}

Jumlah kunjungan pasien yang datang akan berdampak terhadap beban kerja yang akan diterima oleh masing-masing perawat karena berkaitan dengan jumlah asuhan yang harus diberikan oleh perawat terhadap masing-masing,maka dari itu pengaplikasian berpikir kritis sangat baik untuk di aplikasikan oleh perawat ketika mengambil keputusan.

Gillies (1994) mengungkapkan bahwa faktor-faktor yang mempengaruhi beban kerja perawat antara lain adalah jumlah klien yang dirawat/hari/bulan/tahun dalam suatu unit, kondisi penyakit atau tingkat ketergantungan klien, rata-rata hari perawatan klien (AvLOS), pengukuran perawatan langsung dan tidak langsung, frekuensi tindakan yang dibutuhkan, rata-rata waktu keperawatan langsung dan tidak langsung.
Jumlah kunjungan pasien akan berimbas pada banyaknya kegiatan produktif yang harus dikerjakan perawat, baik kegiatan keperawatan langsung berdasarkan klasifikasi pasien maupun kegiatan keperawatan tidak langsung.

Antara banyaknya kunjungan pasien di IGD dengan pengaplikasian berpikir kritis memiliki hubungan karena semakin banyak pasien yang melakukan kunjungan di IGD maka seorang perawat harus bekerja dengan cepat dan tepat maka dari itu pengambilan tidakan dan menyelesaikan masalah dengan cara berpikir kritis akan membuat pengambilan keputusan dan cara menyelesaikan masalah menjadi lebih cepat dan tepat yang nantinya akan menghasilkan pemberian ASKEP kepada pasien yang baik dan berkualitas.

Perawat melakukan pengambilan keputusan ketika melakukan setiap tindakan ,sementara itu juga perawat melakukan perencanaan pemberian asuhan keperawatan efektifitas dan ketepatan dalam pengambilan keputusan yang itu dibutuhkan kemampuan untuk 
mengumpulkan data dan keterampilan dalam berpikir kritis.

\section{Berpikir kritis dalam pengambilan keputusan}

Berpikir kritis dalam keperawatan merupakan komponen yang sangat penting dari akuntabilitas profesional dan salah satu aspek yang menentukan kualitas asuhan keperawatan .Perawat yang memiliki kemampuan berpikir kritis akan menunjukan sikap percaya diri,kreatif dalam menyelesaikan masalah ,berpandangan

konseptual,fleksibel,rasa ingin tahu nya sangat tinggi,cara berpikirnya yang kreatif, dan tekun dalam berkerja.

Berpikir kritis merupakan suatu kompetensi yang harus di miliki perawat terutama perawat yang bekerja di IGD karena harus melakukan pekerjaan dengan cepat sehingga pengaplikasian berpikir kritis pada perawat di IGD sangat diperlukan agar dapat memberikan asuhan keperawatan yang berkualitas.

Berpikir kritis juga menjadi suatu yang sangat penting dalam keperawatan akibat semakin kompleksnya pengambilan keputusan klinis dalam pemberian pelayanan keperawatan untuk mengatasi masalah pasien dan akan terjadi resiko yang merugikan kondisi pasien jika perawat melakukan keselahan ketika mengambil keputusan.

\section{Kesimpulan dan saran}

Perlunya pengaplikasian berpikir kritis bagi perawat yang bekerja di IGD dalam mengambil keputusan yang cepat dan tepat sehingga dapat mengurangi resiko yang akan berakibat merugikan pasien. ketika perawat tersebut mengaplikasikan berpikir kritis maka perawat tersebut tidak hanya memandang suatu masalah dari sudut pandang,perawat yang mengaplikasikan berpikir kritis berpeluang memberikan asuhan keperawatan yang lebih baik.

Saran dari kajian ini menyarankan pentingnya meningkatkan berpikir kritis perawat. Karena dengan mengaplikasikan kemampuan berpikir kritis maka akan tepat pula ketika seorang perawat tersebut mengambil keputusan . Selain itu, upaya yang dapat dilakukan untuk meningkatkan kemampuan berpikir kritis perawat antara lain dengan pelatihan dan pendidikan. 


\section{Daftar Pustaka}

Fadhilah,Nailatul.Harahal Wirsma Arif.

Lestari,

Yuniar.(2015).Faktor-faktor yang

Behubungan Dengan Waktu

Tanggap Pada Kasus kecelakaan

Lalu Lintas di Instalasi Gawat

Darurat Umum Pusat Dr.M

Djamil Padang tahun

2013.4(1).195-201

Fathi,A.,\&Simamora,R.H.(2019,

March).Investigating

nurses'coping strategies in their workplace as an indicator of quality of nurses'life in indonesia:a preliminary study.in IOP Conference Series :Earth and Environmental

Science

(vol.248,No .1,p.012031).IOP

Publishing.

Galerasa,A.V.,Sundari,s.(2019).

Penggunaan metode simulalsi

dalam peningkatan critical

thinking:Literature

Review.5(01).17-25.

Haryanti. Aini,F., Purwaningsih, P.

(2013). Hubungan Antara Beban

Kerja Dengan Stres Kerja

Perawat di Instalasi Gawat

Darurat RSUD kabupaten

Semarang.1(01).48-56
Haryanto,Agus.(2014).Hubungan

Berpikir Kritis dan Waktu Tanggap perawat Dengan Kualitas Asuhan Keperawatan di Instalasi Gawat darurat Rumah Sakit Islam Surabaya.Fakultas Kedokteran . Universitas Sebelas Maret.Surakarta

Hendianti,G.N.,Somantri,I., Yudianto.

K.Gambaran Beban Perawat Pelaksana Unit Instalasi Gawat Darurat Rumah Sakit Muhammadiyah Bandung.

$1-14$.

Huriah,Titih.(2018). Metode Student Center Learning Aplikasi Pada Pendidikan Keperawatan.Jakarta :Penerbit Prenademia Group.

Juliadi.,Enimay.(2011). Hubungan Stres Kerja Terhadap Kinerja Perawat di Instalasi Rawap Inap (IRNA) RSUD Kota Dumai.1 (02).77-85.

Kurniawan,Ardhiles Wahyu.(2018). Hubungan Intensi dengan Prilaku Perawat Dalam Pendokumentasian Asuhan Keperawatan di Instalasi Gawat Darurat.4(01).169-174

Kusnanto.(2004).Pengantar Profesi dan Praktik Keperawatan 
Profesional. Jakarta : Penerbit Buku Kedokteran EGC

Mulyaningsih.(2013).Peningkatan

Perilaku Caring Melalui

Kemampuan Berpikir Kritis

Perawat.1(2).100-106

Potter,P.A.,\&Perry,A.G.(2005). Buku

Ajar Fundamental Keperawatan

konsep, Proses dan Praktek (edisi

4).Jakarta : Penerbit Buku

Kedokteran EGC

Puspitaningrum,I.,Hartiti,T. (2017).

Peningkatan Kualitas

ProfesionalMelalui

Pengembangan Keprofesian

Berkelanjutan(PKB). Yogyakarta:

Penerbit Deepublish.

Shalahuddin,Iwan.Yasmin,Ahmad,

Pebrianti,Sandra.(2019).Determin

an Prilaku Petugas Keperawatan

Dalam Penangan Pasien Di

Instalasi Gawat Darurat.5(1).89-

96

Sudono,D.S.,Bambang.,Setya,A.D.,

Darmayanti,N.N.T.,Oktamianti,P.

(2014).Analisis Kompetensi

Perawat Ruang Intensif (Intensive

Care Unit) Rumah Sakit Umum

Tabanan Tahun 2013 .1(01).77-

104. 